\title{
Fungsi dan Peran Konseling Islam Dalam Pendidikan
}

\author{
Abdurrahman \\ Universitas Islam Negeri Sumatera Utara \\ abdurrahman.smj@gmai.com
}

\begin{abstract}
This article discusses the functions and important role of Islamic counseling in education. The method used is descriptive analysis, by exploring all the resources related to Islamic counseling as a means of education. Islam is the Shari'a of Allah for humans, with the provision of the Shari'a that humans worship as a form of realization to serve Allah SWT. In order for humans to be able to bear and realize the great mandate, the Shari'a requires practice, development and formation known as Islamic education. Of course there will be no realization of Islamic law without any effort to forge themselves, and for that we need an educational role to be introduced from generation to generation. Islamic counseling greatly contributes greatly to education. Islam as a religion full of divine values will give a positive value in the world of education. That way, Islamic counseling plays an important role in the world of education. Humans who basically really understand the values of Godhead that are within them.
\end{abstract}

Keywords: Roles and Functions, Islamic Counseling, Education

\begin{abstract}
Abstrak
Artikel ini membahas tentang fungsi serta peran penting konseling Islam dalam pendidikan. Metode yang digunakan adalah deskriptif analisis, dengan menggali segala sumbar yang berkaitan dengan konseling Islam sebagai sarana dalam pendidikan. Islam merupakan syariat Allah bagi manusia, dengan bekal syariat itu manusia beribadah sebagai bentuk perwujudan untuk mengabdi kepada Allah swt. Agar manusia mampu memikul dan merealisasikan amanat besar itu, syariat itu membutuhkan pengamalan, pengembangan dan pembinaan yang dikenal dengan pendidikan Islam. Tentu tidak akan ada perealisasian syariat Islam tanpa adanya upaya penempaan diri, dan untuk itu diperlukan peran pendidikan untuk diperkenalkan dari generasi ke genenerasi berikutnya. Konseling Islam sangat memberikan andil yang sangat besar dalam pendidikan. Islam sebagai agama yang penuh dengan nilai-nilai Ketuhanan, akan memberikan nilai positif dalam dunia pendidikan. Dengan begitu, konseling Islam sangat berperan
\end{abstract}


penting dalam dunia pendidikan. Manusia yang pada dasarnya sangat memahami nilai-nilai Ketuhanan yang ada dalam diri mereka.

Kata Kunci: Peran dan Fungsi, Konseling Islam, Pendidikan

\section{Pendahuluan}

Islam adalah manbaj robbani yang sempurna, diturunkan untuk membentuk pribadi yang sempurna dalam diri manusia. Artinya, pendidikan Islam dapat membentuk pribadi yang mampu mewujudkan keadilan ilabiyah dalam komunitas manusia serta dapat mendayagunakan potensi alam dengan pemakaian yang adil. Di sisi lain Allah telah membekali manusia dengan kemampuan untuk belajar dan mengetahui serta memfasilitasinya berupa penglihatan, penengaran dan hati. Dengan perangkat-perangkat inilah manusia diamanatkan Allah untuk menjadi khalifah memimpin dan memakmurkan bumi ini.

Di berbagai institusi pendidikan, tidak terkecuali institusi pendidikan yang dilabeli dengan Islam terdapat berbagai praktik perilaku yang dilarang dalam ajaran Islam. Tentunya hal ini disebabkan tidak dipraktikkannya ilmu pendidikan dan merajalelanya kecelakaan pendidikan. Pendidikan lebih diartikan sekedar penguasaan konten bagi peserta didik dan menjadikan pembinaan kepribadian sebagai upaya sampingan atau tambahan dalam pendidikan.

Konseling Islam sebagai sub sistem pendidikan merupakan bagian tidak terpisahkan dalam pendidikan Islam. Sayangnya para praktisi pendidikan kurang bahkan tidak memahami bahwa antara sistem pengajaran, bimbingan dan supervisi/pengawasan merupakan satu kesatuan yang utuh. Dalam keterkaitannya dengan bimbingan inilah peran dan fungsi konseling Islami akan dielaborasi dan ditampilkan sebagai suatu keniscayaan dalam penyelenggaraan pendidikan Islam. Di sisi lain juga untuk menghindarkan terjadinya disorientasi terhadap kehadiran konseling Islami dalam penyelenggaraan pendidikan Islam.

\section{Hasil dan Pembahasan}

\section{Rumusan Konseling Islami}

Istilah konseling yang digunakan dalam tulisan ini merupakan alih bahasa dari bahasa Inggris "counseling” yang berarti advis, informasi, dialog, opini atau pertimbangan yang diberikan oleh seseorang kepada orang lain sehubungan dengan pembuatan keputusan atau tindakan yang akan datang. Konsepsi konseling yang berakar pada "Vocational Guidance" yang dipelopori oleh Frank Person di Boston tahun 1908, telah berkembang sebagai layanan utama bimbingan dalam pendidikan. 
Istilah konseling disebut juga dengan penyuluh dan biasanya kata konseling ini terangkai dengan kata "bimbingan", yakni Guidance and Counseling". Dalam istilah Indonesia menjadi "bimbingan dan penyuluhan" atau "bimbingan dan konseling". Sementara itu di dalam bahasa Arab sebagaimana yang didefenisikan oleh al-Khouly konseling disebut dengan al-Irsyãd ${ }^{2}$. Secara etimologi kata irsyãd - arsyada berarti badã, dalla yang dalam bahasa Indonesia berarti petunjuk, sedangkan kata Istisyãrah berarti Istisyãrahu talaba minbu al masyurah/al-nashihah, dalam bahasa Indonesia berarti meminta nasihat ${ }^{3}$. Athiyah menerangkan bahwa konseling bermaksud memberikan pelayanan atau penerangan kepada seseorang dalam suatu proses pertemuan antara dua orang, dimana salah seorang diantaranya mengalami kegoncagan yang disebabkan oleh problem pribadi yang tidak dapat diselesaikannya sendiri ${ }^{4}$.

Untuk lebih mendekatkan pamahaman perlu dikemukakan bahwa dalam konseling terjadi pertemuan tatap muka antara konselor (orang yang memberi bimbingan) dan konseli (orang yang menerima bimbingan). Konseling ini dipandang sebagai inti proses pemberian bantuan yang esensial bagi upayan layanan bimbingan kepada seseorang (siswa) pada saat mereka berusaha menyelesaikan problema yang mereka hadapi ${ }^{5}$. Namun perlu dicatata bahwa dalam praktiknya konseling harus dilakukan oleh seseorang yang telah terlatih/profesional.

Secara lebih jelas Zulkifli Akbar menyatakan konseling Islami adalah serangkaian kegiatan yang dilaksanakan oleh konselor yang kompeten dengan individuyang bertujuan untuk membantu individu dlam memecahkan masalahnya sendiri, dengan menggunakan ajaran-ajaran Islam dan pemikiran logis yang dikaitkan dengan ajaran Islam agar memperoleh kebahagiaan dunia dan akhirat ${ }^{6}$.

Berkaitan dengan defenisi bimbingan konseling Islam, Munandir Menyatakan bimbingan konseling Islami sesuai dengan penggunaan kata sifatnya, menunjukkan landasan dan arah bantuan yang dituju, yaitu Islam yang meliputi konsepsinya tentang manusia (dan tentang berbagai hal lain), ajaran-

h. 45 .

${ }^{2}$ Muhammad Ali al-Khouly. Qamus alTarbiyah (Libanon: Dar al 'ilm li al Malayin. 1981).

${ }^{3}$ Jubran Mas'ud. Raid al Tullab (Beirut: Dar al 'Ilm li al Malayin, 1967), h.57 dan 70.

${ }^{4}$ Athiyah Mahmud Hana. Al Syahsiyah wa al Shibah al Nafsiyah (Kairo: Maktabah al Nahdah al Misriyah. 1958). h. 145.

${ }^{5}$ A. Edward Hoffman. An Analysis of Counselor Subroles. Journal of Counseling Psychology. 1. 1959. h. 61

${ }^{6}$ Zulkifli Akbar. Dasar-dasar Konseptual Penanggungan Masalab Bimbingan dan Konseling Islami di Bidang Pernikahan, Kemasyarakatan dan Keagamaan (Yogyakarta: UII. 1987). h. 12.

ISLAMIC COUNSELING : Jurnal Bimbingan dan Konseling Islam

vol. 3, no. 1, 2019 | p ISSN 2580-3638; e ISSN 2580-3646

http://journal.staincurup.ac.id/index.php/JBK 
ajarannya, peraturan-peraturannya, sepanjang menyangkut orang perseorangan, ajaran itu mengenai segala dimensi hubungan dan pergaulannya

Beranjak dari defenisi yang dikemukakan para pakar bimbingan konseling Islami di atas dapat dirumuskan bahwa konseling Islami itu adalah suatu proses konseling yang berorientasi pada ketentraman hidup manusia dunia akhirat. Pencapaian rasa tentram (sakinab) itu melalui pendekatan diri pada lindungan Allah. Terapi sakinah itu akan menghantarkan individuuntuk mampu menyelesaikan masalah kehidupannya. Tegasnya konseling Islami adalah suatu proses yang menuju aktualisasi kebahagiaam hidup dunia dan akhirat. Prinsipprinsip inilah yang sekaligus membedakan konsep konseling Islam dengan konsep konseling yang dihasilkan dari pengetahuan dan empirik Barat. Sifat Islam yang melekat pada kata konseling bukan sekedar label yang tanpa makna, melainkan suatu kata yang melengkapi serta menyempurnakan konseling itu sendiri.

Meskipun tergolong sebagai fenomena baru, sesungguhnya konseling Islam sama tuanya dengan kegiatan dakwah Islam di tengah-tengah masyarakat. Ini tidak lain karena konseling pada hakikatnya merupakan bagian penting dari kehidupan beragama itu sendiri. Dan untuk konteks masyarakat muslim konseling Islami yang terlembagakan setidaknya sudah berlangsung sejak berdirinya pondok pesdantren. Kompleksitas kehidupan umat yang semakin tinggi berlaku paralel dengan meningkatnya keperluan terhadap konseling Islam dan selanjutnya konseling pendidikan Islami ${ }^{8}$

Konseling Islam yang berkarakteristik Islam merupakan proses konseling yang berorientasi kepada tujuan pendidikan Islam. Islam yang berwawasan rahmatan lil ãlamin mengemban missi untuk menghantarkan manusia menuju kehidupan sakinah yang menjadi dambaan bagi setiap individu. Kehidupan sakinah ini adalah sebagai ekspresi dari prediket al nafs al mutmainnah, yang menurut al Syarkawi memiliki ciri-ciri: sakinah, ridã, tawakkal, ibsyãr dan sabar. Ciri-ciri tersebut akan senantiasa tercermin dalam setiap menghadapi cobaan hidup. Dalam mencapai al kamalah al akblãqiyah (kesempurnaan budi pekerti), tidak mengenal rasa takut, gelisah dan kegoncangan jiwa, karena segala persoalan dikembalikan kepada keputusan dan keridaan Allah semata ${ }^{9}$.

Konseling Islam yang dilakuakan terhadap individu/siswa sebagai upaya merekonstruksi serta mengaktualisasikan kembali konsep diri agar dapat mencapai al nafs al mutmainnah tersebut. Kawasan garapannya yang utama adalah hati (al qalb) sebagaimana halnya dengan tujuan pendidikan Islam itu sendiri yang beraspek tarbiyatul al qulub, yakni berupa latihan jiwa dengan menitik beratkan

\footnotetext{
${ }^{7}$ Munandir. Beberapa Pemikiran Mengenai Bimbingan Konseling Islami (Yogyakarta: UII, 1987. h. 3.

${ }^{8}$ Saiful Akhyar, Slide Materi Perkuliahan Konseling Islami

${ }^{9}$ Baca Hasan Muhammad al Syarqawi. Nahwa Ilmin Nafsin (Mesir: al Haiah al Nisriyyah al-‘Ammah li al-Kitab. 1979). h. 289 - 290.
} 
pada niat dalam hati, dengan senantiasa berupaya menjauhkan segala perasaan was-was serta niat yang tidak baik.

Berdasarkan berbagai ulasan di atas, akan dikemukakan rumusan konseling Islam sebagai berikut :

a. Konseling Islami adalah suatu layanan bimbingan psikologik yang berprinsip ilmiah dan berkarakteristik Islami.

Prinsip ilmiah dapat dibuktikan antara lain dengan pembuktian kebenaran ajaran Islam. Namun jika ada firman-firman Allah yang belum dapat dibuktikan kebenarannya oleh ilmu pengetahuan manusia, bukan berarti ajaran Islam tersebut tidak sesuai dengan prinsip-prinsip ilmiah, tetapi ilmu pengetahuan manusia itulah yang belum mampu menjangkau aktualisasinya.

b. Secara konsepsional konseling Islami dibangun di atas pondasi sumbersumber ajaran Islam. Pelaksanaan pendidikan nabi di Madinah, yakni al Syffah dimana fungsi dan peran nabi pada waktu itu adalah sebagai konselor yang memberi pengarahan serta memberi petunjuk bagi pemecahan problem yang dihadapi sahabat. Hal ini sekaligus menjadi titik tolak inspirasi proses konseling Islami

c. Konseling Islami berorientasi pada kehidupan sakinah, mutmainnah, mencapai kebahagiaan hidup dunia dan akhirat karena senantiasa dekat dengan Allah. Aktualisasi kembali pada konsep diri bagi klien (konsele) pada hakikatnya adalah pembersihan hati dari perbuatan maksiat agar ia dapat memiliki qalbun salīm dan nafs mutmainnah.

d. Sebagai layanan psikologik, konseling Islami mengacu pada asas dan prinsip psikologi Islami. Dalam membangun asas dan prinsipnya berpijak pada konsepsi manusia dalam pandangan Islam.

Dalam kaitannya dengan tujuan konseling Islami tentunya sejalan dengan tujuan pendidikan Islam, dimana konseling Islami ditujukan untuk menyadarkan manusia tentang keberadaannya sebagai makhluk Allah dan membantunya untuk menyelesaikan masalah kehidupan yang dihadapinya, sehingga ia dapat mengambil keputusan dan selanjutnya bertindak dengan berpedoman pada ajaran Islam. Sekaligus membina mentalnya agar ia tertuntun ke arah kehidupan yang sakinah dengan hati, perasaan yang tenang, tentram (qalbun salim dan nafs mutmainnah) demi mencapai kesejahteraan dan kebahagiaan hidup, baik di dunia maupun di akhirat. Hal ini sejalan dengan tujuan pendidikan Islam yaitu :

a. Memelihara fitrah manusia menuju kedewasaan

b. Mengembangkan potensi dan kesiapan yang beragam

c. Mengarahkan potensi dan kesiapan kepada kebaikan/kesempurnaan 
d. Prosesnya berlangsung secara bertahap ${ }^{10}$

Selanjutnya pendidikan Islam itu sendiri dipahami dan dikembangkan dari ajaran dan nilai fundamental yang terkandung dalam Alquran dan Sunnah yang dapat berwujud pemikiran atau teori yang dibangun dan dikembangkan dari kedua sumber dasar tersebut. Hal tersebut dikarenakan manusia dalam pandangan Islam memiliki berbagai potensi yang akan dikembangkan, maka tujuan pendidikan Islam berfungsi untuk membentuk kepribadian manusia secara kaffah.

Pendidikan Islam seyogyanya menyediakan wahana dan sarana untuk kepentingan individual dan untuk kepentingan kolektif. Pendidikan Islam harus memperhatikan tanggung jawab iman, akhlak, fisik, psikis, sosial dan seksual. Tentunya dalam mengaplikasikan konsep tersebut, maka rukun iman dan rukun Islam merupakan proses aktualisasi potensi diri manusia secara totalitas. Selain sebagai petunjuk ritual, pokok pikiran dari kedua rukun dimaksud memberikan bimbingan untuk mengenal dan memahami perasaan diri sendiri dan orang lain, memotivasi diri serta mengelola emosi ${ }^{11}$.

\section{Tugas dan Fungsi Pendidikan Islam}

Pada hakikatnya pendidikan Islam adalah suatu proses yang berlangsung secara kontiniu dan berkesinambungan. Berdasarkan hal ini maka tugas dan fungsi yang harus diemban oleh pendidikan Islam adalah pendidikan manusia seutuhnya dan berlangsung sepanjang hayat. Konsep ini bermakna bahwa tugas dan fungsi pendidikan memiliki sasaran pada peserta didik yang senantiasa tumbuh dan berkembang secara dinamis mulai dari kandungan sampai akhir hayatnya.

Secara umum tugas pendidikan Islam adalah membimbing dan mengarahkan pertumbuhan dan perkembangan peserta didik dari tahap ke tahap kehidupannya sampai mencapai titik kemampuan optimal. Sementara fungsinya adalah menyediakan fasilitas yang dapat memungkinkan tugas pendidikan berjalan dengan lancar ${ }^{12}$. Dengan demikian dapat dipahami bahwa tugas pendidikan Islam dilakukan melalui tiga pendekata. Ketiga pendekatan itu adalah: pendidikan Islam sebagai pengembangan potensi, proses pewarisan budaya serta interaksi antara potensi dan budaya. Sebagai pengembangan potensi, tugas pendidikan Islam adalah menemukan dan mengembangkan kemampuan dasar yang dimiliki peserta didik, sehingga dapat diaktualisasikan dalam kehidupannya sehari-hari ${ }^{13}$.

${ }^{10}$ Saiful Akhyar, Slide Materi Perkuliahan Konseling Islami
${ }^{11}$ Saiful Akhyar, Slide Materi Perkuliahan Konseling Islami
${ }^{12}$ M. Arifin. Filsafat Pendidikan Islam (Jakarta: Bina Aksara. 1987). h. 33 - 34
${ }^{13}$ Hasan Langulung. Pendidikan Islam Menghadapi Abad Ke - 21 (Jakarta: Pustaka Al Husna. 1988). h. 57 
Sebagai pewaris budaya tugas pendidikan Islam adalah alat transmisi unsur-unsur pokok budaya dari satu generasi ke generasi berikutnya, sehingga identitas umat tetap terpelihara dan terjamin dalam tantangan zaman. Adapun sebagai interaksi antara potensi dan budaya, tugas pendidikan Islam adalah sebagai transaksi (memberi dan mengadopsi) antara manusia dan lingkungannya. Dengan proses ini, peserta didik (manusia) akan dapat menciptakan dan mengembangkan keterampilan-keterampilan yang dapat digunakan untuk mengubah atau memperbaiki kondisi-kondisi kemanusiaan dan lingkungannya ${ }^{14}$.

Untuk menjamin terlaksananya tugas pendidikan Islam secara baik, hendaknya terlebih dahulu dipersiapkan situasi dan kondisi pendidikan yang bernuansa elastis, dinamis dan kondusif yang memungkinkan bagi pencapaian tugas tersebut. Hal ini berarti bahwa pendidikan Islam dituntut untuk dapat menjalankan fungsinya baik secara struktural maupun institusional. Artinya secara struktural pendidikan Islam menuntut adanya struktur organisasi yang mengatur jalannya proses pendidikan, baik pada dimensi vertikal maupun horizontal. Sementara institusional ia mengandung implikasi bahwa proses pendidikan yang berjalan hendaknya dapat memenuhi kebutuhan dan mengikuti perkembangan zaman yang terus berkembang. Untuk itu diperlukan kerjasama berbagai jalur dan jenis pendidikan, mulai dari sistem pendidikan sekolah maupun pendidikan luar sekolah.

Bila dilihat secara operasional, fungsi pendidikan dapat dilihat dari dua bentuk, yaitu :

a. Alat untuk memelihara, memperluas dan menghubungkan tingkat-tingkat kebudayaan, nilai-nilai tradisi dan sosial serta ide-ide masyarakat dan nasional

b. Alat untuk mengadakan perubahan, inovasi dan perkembangan. Pada garis besarnya upaya ini dilakukan melalui potensi ilmu pengetahuan dan skill yang dimiliki, serta melatih tenaga-tenaga manusia (peserta didik) yang produktif dalam menemukan perimbangan perubahan sosial dan ekonomi yang kian dinamis ${ }^{15}$

Melihat pada tugas dan fungsi pendidikan Islam di atas, sangat terkait dengan tujuan konseling Islami dalam pendidikan. Sebagaimana yang dikemukakan Thohari Musnamar sebagai berikut :

a. Membantu individu mencegah timbulnya problem-problem yang berkaitan dengan kegiatan belajar, antara lain dengan jalan :

1) Membantu individu memahami hakikat belajar/pendidikan menurut Islam

${ }^{14}$ Langulung. Pendidikan. h. 63

${ }^{15}$ Rahmayulius dan Samsul Nizar. Filafat Pendidikan Islam Telaah Sistem Pendidikan dan Pemikiran Para Tokohnya (Jakarta: Kalam Mulia. 2011). h. 93

ISLAMIC COUNSELING : Jurnal Bimbingan dan Konseling Islam

vol. 3, no. 1, 2019 | p ISSN 2580-3638; e ISSN 2580-3646

http://journal.staincurup.ac.id/index.php/JBK 
40 | ISLAMIC COUNSELING: Jurnal Bimbingan dan Konseling Islam, vol. 3, no. 1, 2019

2) Membantu individu memahami tujuan dan kedudukan belajar/ pendidikan menurut Islam

3) Membantu individu memahami faktor-faktor yang mempengaruhi keberhasilan belajar/pendidikan

4) Membantu individu menyiasati kegiatan belajar/pendidikan agar berhasil.

5) Membantu individu melakukan kegiatan belajar/pendidikan sesuai dengan ketentuan (syariat) Islam.

b. Membantu individu memecahkan masalah-masalah yang berkaitan dengan belajar/pendidikan, antara lain dengan jalan :

1) Membantu individu agar mampu memahami (menganalisis dan mendiagnosis) problem yang dihadapinya

2) Membantu individu memahami kondisi dirinya dan lingkungannya

3) Membantu individu memahami dan menghayati cara-cara mengatasi masalah belajar/pendidikan menurut atau yang sesuai dengan ajaran Islam

4) Membantu individu menetapkan pilihan upaya pemecahan masalah yang dihadapinya sesuai dengan ajaran Islam

c. Membantu individu memelihara situasi dan kondisi kegiatan belajar/pendidikannya agar tetap baik dan mengembangkannya agar jauh lebih baik, antara lain dengan cara :

1) Membantu individu memelihara situasi dan kondisi belajar/pendidikannya yang semula pernah terkena problemdan telah teratasi agar tidak menjadi permasalahan kembali

2) Mengembangkan situasi dan kondisi belajar/pendidikan menjadi lebih baik ${ }^{16}$

\section{Esensi Konseling Islami Dalam Pendidikan}

Semakin kompleksnya kehidupan dan kebutuhan manusia berdampak pada banyaknya perubahan pada diri seseorang. Hal ini berakibat pada semakin banyaknya orang yang memerlukan bantuan orang lain dalam menyelesaikan masalah yang dihadapinya dalam kehidupan tersebut. Seiring dengan perubahan itu koneling Islam pun berubah kearah yang lebih lengkap. Diperlukan teknik dan pendekatan, bahkan harus profesional. Masalah-masalah siswa tidak cukup hanya diselesaikan guru yang mengajar di kelas, tetapi perlu penanganan konselor melalui program konseling Islami.

Dalam tataran operasional konseling Islami dilakukan berlandaskan pada ajaran Islam dengan tujuan untuk menyadarkan manusia tentang keberadaannya sebagai makhluk Allah dan membantunya untuk menyelesaikan masalah kehidupan yang sedang dan akan dihadapinya. Dengan demikian ia akan dapat mengambil keputusan dan selanjutnya bertindak dengan berpedoman pada ajaran Islam demi mencapai kesejahteraan dunia dan akhirat. Paradigma ini

${ }^{16}$ Thohari Musnamar. Dasar-Dasar Konseptual Bimbingan dan Konseling Islami (Yogyakarta: UII Press. 1992). h. 93 
dalam perkembangan keilmuan konseling Islami dikenal dengan konseling triadic. Kalau dalam praktik konseling konvesional proses penyelesaian masalah terbatas pada komunikasi intensif antara konselor dan klien, maka dalam proses konseling Islami selain dari intensifitas komunikasi konselor dan klien, Allah sebagai sebab dari segala sebab dijadikan sebagai alasan pemungkas mengapa manusia atau klien harus bisa keluar dari masalah yang sedang dihadapi, atau paling tidak bisa menerima atau bersabar atas sesuatu yang memberatkan dirinya yang dikenal dengan identitas sebagai "masalah".

Sejalan dengan uraian di tas, maka tugas pendidik dalam proses pendidikan adalah mendidik ${ }^{17}$. Aktivitas mendidik itu sebahagian dilakukan dalam bentuk mengajar, melatih, membimbing, mengarahkan, memberi dorongan, memuji, memberi contoh atau keteladanan, membiasakan bahkan memberi hadiah dan hukuman. Karenanya tugas mendidik bukan hanya sekedar mengajar, tetapi juga memotivasi, mengarahkan, memberi penguatan, mengklarifikasi dan memfasilitasi proses pembelajaran, yaitu proses dimana peserta didik dibina agar dapat merealisasikan seluruh potensi yang dimilikinya secara maksimal ${ }^{18}$.

Dalam Islam, tugas utama yang harus demban pendidik pada dasarnya adalah mengenalkan dan meneguhkan kembali perjanjian suci manusia terhadap Allah swt. Untuk itu seorang pendidik harus berupaya mengantarkan peserta didiknya ke arah pengenalan kembali syahadâh kepada Allah swt. yang telah

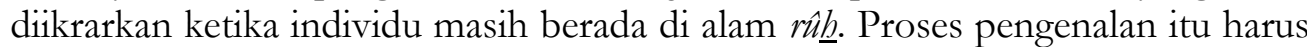
berlanjut pada upaya edukatif untuk meneguhkan syahadâh, yakni konsistensi pengakuan akan ke Maha Esaan Allah swt. dalam seluruh sikap, amal dan perbuatan sepanjang kehidupan.

Senyatanya dalam kelangsungan proses pendidikan diberbagai instansi pendidikan Islam tidak sedikit siswa yang mengalami masalah, baik yang berkaitan dengan proses pembelajaran/akademik maupun yang berkaitan dengan masalah diri pribadi. Di sisi lain tidak sedikit siswa yang kurang bahkan tidak mampu mengatasi atau keluar dari masalah yang melingkupi kehidupannya. Ekses yang timbul sangat beragama. Disorientasi terhadap tujuan pendidikan, mental disorder, perilaku salah suai. Pathologi sosial, degradasi mental, penurunan prestasi belajar, konflik internal teman sebaya, konplik keluarga bahkan konplik dalam memahami eksistensi tuhan. Dalam hal ini diperlukan tenaga profesional yang dapat membantu peserta didik dalam mengenali dan mencarikan solusi 1992). h. 78

${ }^{17}$ Ahmad Tafsir, Ilmu Pendidikan Dalam Prespektif Islam (Bandung: Remaja Rosdakarya.

${ }^{18}$ Baca Hasan Langulung. Asas-asas Pendidikan Islam (Jakarta: Al Husna. 1988). h. 86 87. 
terhadap masalah yang sedang mereka hadapi. Selain konselor, guru melalui pemberdayaan layanan konsultasi dengan guru pembimbing atau konselor dapat berperan melakukan proses konseling Islam guna mengembalikan peserta didik kepada fitrahnya.

Dengan demikian, melalui pendidikan Islam pendidik/konselor Islami berupaya mengantarkan peserta didik pada keimanan dan kedekatan kepada Allah swt. Agar tujuan itu tercapai, maka pendidik/konselor harus berusaha mensucikan diri atau jiwa peserta didiknya. Sebab hanya diri dan jiwa-jiwa yang suci sajalah yang dapat menuju dan dekat dengan Allah swt. Sebagaimana dikemukakan An-Nahlawi, selain bertugas mengalihkan berbagai pengetahuan dan keterampilan kepada peserta didik, tugas utama yang harus dilakukan pendidik adalah taqkiyah al nafs, yaitu mengembangkan, membersihakan dan mengangkat jiwa peserta didik agar sampai kepada penciptanya, menjauhkannya dari kejahatan dan menjaga agar mereka tetap berada pada fitrabnya ${ }^{19}$

Kesempurnaan ajaran Islam menyimpan khazanah-khazanah berharga yang dapat digunakan untuk membantu menyelesaikan problema yang dihadapi oleh manusia dalam kehidupannya. Secara operasional khazanah-khazanah tersebut tertuang dalam konsep konseling Islami yang secara praktis tercermin dalam proses face to face relationship (pertemuan tatap muka) atau personal contect (kontak pribadi) antara seorang konselor yang kompeten dalam bidangnya dengan seorang klien (konsele) yang sedang menghadapi dan sedang berjuang menyelesaikan problema kehidupannya. Dalam keadaan seperti inilah konseling Islami benar-benar berperan bagi penyelesaian problem kehidupan peserta didik ${ }^{20}$.

Berkaitan dengan hal di atas, eksistensi konseling Islami dalam pendidikan Islam merupakan satu kesatuan yang tidak terpisahkan. Siswa sebagai objek garapan dalam proses pembelajaran sekaligus objek dalam layanan konseling Islami. Sebagai objek proses pembelajaran siswa harus diperkenalkan dengan harkat dan martabatnya sebagai manusia yang melingkupi :

a. makhluk yang beriman dan bertaqwa kepada Tuhan Yang Maha Esa

b. makhluk yang paling indah dan sempurna dalam penciptaan dan pencitraannya

c. makhluk yang paling tinggi derajatnya

d. khalifah di muka bumi

e. pemilik hak-hak asasi manusia $^{21}$

19 Abdurrahman an-Nahlawi, Prinsip-prinsip dan Metode Pendidikan Islam Dalam Sekolah, Keluarga dan Masyarakat. Terjemah. Herry Noer Ali (Bandung: CV. Diponegoro. 1992). h. 239.

${ }^{20}$ Selanjutnya Baca Tesis Saiful Akhyar. Konseling Islami dan Urgensinya dalam Kesehatan Mental. Fakultas Pasca Sarjana dan Pendidikan Doktor Institut Agama Islam Negeri Sunan Kalijaga Yogyakarta. 1990.

${ }^{21}$ Prayitno. Dasar Teori dan Praksis Pendidikan (Jakarta: Grasindo. 2009). h. 14 
Di sisi lain siswa juga harus diperkenalkan terhadap dimensi kehidupannya yang meliputi:

a. Dimensi kefitrahan, kata kuncinya yang dikandungnya adalah kebenaran dan keluhuran. Dengan dua kata kunci ini dapat dimaknai bahwa individu manusia itu pada dasarnya bersih dan mengarahkan diri kepada hal-hal yang benar dan luhur, serta menolak hal-hal yang salah, tidak berguna dan remeh serta tidak terpuji.

b. Dimensi keindividualan, kata kuncinya yang dikandungnya adalah potensi dan perbedaan. Bahwa setiap individu pada dasarnya memiliki potensi, baik potensi fisik maupun mental psikologis, seperti kemampuan intelegensi, bakat dan kemampuan pribadi lainnya. Potensi ini dapat berbeda-beda antar individu, ada yang berpotensi sangat tinggi, tinggi, sedang, kurang dan kurang sekali

c. Dimensi kesosialan, kata kuncinya yang dikandungnya adalah komunikasi

d. dan kebersamaan. Dengan bahasa verbal dan non verbal manusia menjalin komunikasi dengan individu lain. Di samping itu individu juga menggalang kebersamaan dengan individu lain dalam berbagai bentuk, seperti persahabatan, kekeluargaan dan organisasi formal maupun non formal.

e. Dimensi kesusilaan, kata kunci yang dikandungnya adalah nilai dan moral. Dalam dimensi ini digarisbawahi kemampuan dasar setiap individu untuk memberikan penghargaan terhadap sesuatu, dalam rentang penilaian tertentu. Sesuatu dapat dinilai sangat tinggi (misalnya dengan diberi label baik), sedang (dengan label cukup) atau rendah (dengan label kurang). Rentang penilaian itu dapat pula dipersempit atau diperlebar. Misalnya dengan rentang baik, cukup, kurang diperlebar menjadi baik, baik sekali, cukup, kurang, kurang sekali.

f. Penilaian yang dibuat oleh sekelompok individu tentang sesuatu yang sangat penting untuk kehidupan bersama seringkali ditetapkan sebagai standart baku. Standart baku inilah yang selanjutnya dijadikan patokan untuk menetapkan boleh tidaknya sesuatu hal dilakukan oleh individu. Inilah yang disebut moral.

g. Dimensi keberagamaan, kata kunci yang dikandungnya adalah iman dan taqwa. Bahwa setiap individu pada dasarnya memiliki kecenderungan dan kemampuan untuk mempercayai adanya Allah serta mematuhi segenap aturan dan perintah-Nya. Keimanan dan ketaqwaan ini dibahas dalam agama yang dianut individu.

Dalam kaitannya dengan esensi konseling Islami dalam pendidikan Islam, bahwa pendidikan Islam harus mengacu pada masing-masing dimensi yang ada pada diri setiap individu. Di sisi lain agar terinternalisasi pada diri peserta didik segenap program layanan konseling Islami harus berisikan pengetahuan dan pemahaman terhadap kandungan dimensi tersebut. Untuk itu baik guru maupun konselor di 
sekolah dituntut agar memahami secara lebih rinci akan daya-daya yang ada pada individu atau peserta didik, seperti: daya taqwa, cipta, rasa, karsa dan karya.

Daya taqwa merupakan basis dan kekuatan pengembangan yang secara hakiki ada pada diri manusia untuk mengimani dan mengikuti perintah Allah swt. Daya cipta bersangkut paut dengan akal, pikiran, fungsi kecerdasan, fungsi otak. Daya rasa mengacu pada kekuatan perasaan atau emosi yang sering disebut sebagai unsur afektif. Daya karsa merupakan kekuatan yang mendorong individu untuk melakukan sesuatu, secara dinamis bergerak dari satu posisi ke posisi lain baik arti psikis maupun keseluruhan diri. Daya karsa ini mengarahkan individu untuk mengaktifkan dirinya untuk berkembang, untuk berubah dan keluar dari kondisi status quo. Selanjutnya daya karya mengarah pada dihasilkannya produk-produk nyata yang secara langsung dapat digunakan atau dimanfaatkan oleh diri sendiri, orang lain dan/atau lingkungan ${ }^{22}$.

Penampilan kemanusiaan peserta didik sehari-hari akan tampak melalui aktualisasi dimensi-dimensi kemanusiaannya, yaitu dimensi kefitrahan, keindividualan, kesosialan, kesusilaan dan keberagamaannya. Penampilan kelima dimensi kemanusiaan ini sesungguhnyalah merupakan aktualisasi keseluruhan spektrum harkat dan martabat manusia yang telah terkembangkan berkat pengembangan daya yang ada pada individu/peserta didik melalui pendidikan Islam. Pendidikan Islam yang difahami dan dikembangkan dari ajaran dan nilai fundamental yang terkandung dalam sumber dasar (Alquran dan Sunnah), dapat berwujud pemikiran atau teori yang dibangun atau dikembangkan dari kedua sumber dasat tersebut.

Upaya pendidikan Islam dengan campur tangan guru/konselor Islami melalui layanan konseling Islami yang berfokus pada pengembangan daya-daya yang ada dan dimensi kemanusiaan dengan dasar hakikat kemanusiaan akan secara langsung mengisi dimensi-dimensi kemanusiaan yang hasil akhirnya terujud dalam kehidupan sehari-hari. Aktualisasi ini akan menampilkan derajat sosok keutuhan individu manusia sesuai dengan harkat dan martabat manusia yang dimaksudkan. Menjadi manusia seutuhnya dalam kehidupan (dunia dan akhirat) adalah tujuan penciptaan manusia oleh Allah swt. Untuk tujuan itulah hakikat manusia dilengkapi dengan lima dimensi disertai lima daya sebagai perangkat instrumen dasar bagi pengembangan seluruh komponen harkat dan martabat manusia. Hanya dengan pengembangan lewat program konseling Islami dalam bingkai pendidikan Islam, daya-daya itu seoptimal mungkin perwujudan manusia seutuhnya akan dapat tercapai.

Permasalahan Individu itu terumuskan dalam bentuk : Ketaqwaan yang terputus, daya cipta yang lemah, daya rasa yang tumpul, daya karsa yang mandeg, daya karya yang mandul. Gizi yang rendah, pendidikan yang macet, sikap dan

${ }^{22}$ Uraian lebih rinci baca Prayitno. Dasar Teori dan Praksis Pendidikan Jakarta: Grasindo. 2009). h. $16-25$. 
perlakuan yang menolak dan kasar, budaya yang terbelakang, kondisi insidental yang merugikan. Rasa aman yang terancam, kompetensi yang mentok, aspirasi yang terkungkung, semangat yang layu, kesempatan yang terbuang.

\section{Penutup}

Keberhasilan usaha belajar/pendidikan seseorang itu dipengaruhi banyak faktor, dari dalam diri individu itu sendiri maupun dari luar dirinya. Karena banyaknya faktor yang mempengaruhi kegiatan belajar /pendidikan seseorang/peserta didik, maka tidak sedikit dari mereka yang dalam usaha belajar/pendidikannya mengalami kesulitan. Tegasnya individu tidak bisa berhasil dalam belajarnya, tidak mencapai tujuan seperti yang diharapkan karena banyaknya berbagai hal yang mengganggu baik di dalam maupun di luar dirinya. Ketidak mampuan memenuhi berbagai keperluan di luar diri akan berdampak pada masalah. Unsur-unsurnya mencakup gizi, pendidikan, sikap dan perlakuan yang menolak dan kasar, budaya dan kondisi insidental (kondisi yang tidak diinginkan keberadaannya. Selanjutnya ketidak mampuan dalam memenuhi tuntutan dalam diri juga akan berdampak pada timbulnya masalah. Unsurunsurnya mencakup rasa aman, kompetensi, aspirasi, semangat dan kesempatan. Tidak tersahutinya pemenuhan terhadap unsur-unsur ini sekaligus menjadi pemicu terganggunya daya yang ada pada manusia, yaitu daya taqwa, cipta, rasa, karsa dan karya.

Konseling Islami dengan berbagai bentuk layanan dan kegiatan pendukungnya berupaya memfasilitasi terpenuhinya unsur-unsur kebutuhan manusia/peserta didik tersebut melalui pengoptimalan potensi diri manusia/peserta didik semaksimal mungkin. Dengan demikian tujuan tertinggi yang ingin dicapai pendidikan Islam untuk mewujudkan manusia muslim yang bersyahadâh kepada Allah swt. akan terealisir.

\section{Daftar Pustaka}

Abdurrahman an-Nahlawi, Prinsip-prinsip dan Metode Pendidikan Islam Dalam Sekolah, Keluarga dan Masyarakat. Terjemah. Herry Noer Ali (Bandung: CV. Diponegoro. 1992).

A. Edward Hoffman. An Analysis of Counselor Subroles. Journal of Counseling Psychology. 1. 1959.

Ahmad Tafsir, Ilmu Pendidikan Dalam Prespektif Islam (Bandung: Remaja Rosdakarya. 1992).

Ahmad Tafsir, Ilmu Pendidikan Dalam Prespektif Islam (Bandung: Remaja Rosdakarya. 1992).

Athiyah Mahmud Hana. Al Syabsiyah wa al Shibah al Nafsiyah (Kairo: Maktabah al Nahdah al Misriyah. 1958). 
Blum, Milton L and Balinsky Benyamin. Counseling and Psychology (Tokyo: Prentice Hall. 1973).

Hasan Langulung. Asas-asas Pendidikan Islam (Jakarta: Al Husna. 1988).

Hasan Langulung. Pendidikan Islam Menghadapi Abad Ke - 21 (Jakarta: Pustaka Al Husna. 1988).

Hasan Muhammad al Syarqawi. Nabwa Ilmin Nafsin (Mesir: al Haiah al Nisriyyah al-'Ammah li al-Kitab. 1979).

Jubran Mas’ud. Raid al Tullab (Beirut: Dar al 'Ilm li al Malayin, 1967).

Muhammad Ali al-Khouly. Qamus al-Tarbiyah (Libanon: Dar al 'ilm li al Malayin. 1981).

Munandir. Beberapa Pemikiran Mengenai Bimbingan Konseling Islami (Yogyakarta: UII, 1987.

M. Arifin. Filsafat Pendidikan Islam (Jakarta: Bina Aksara. 1987).

Prayitno dan Erman Amti. Dasar-dasar Bimbingan dan Konseling (Jakarta: Rineka Cipta. 2004).

Prayitno. Dasar Teori dan Praksis Pendidikan (Jakarta: Grasindo. 2009).

Rahmayulis dan Samsul Nizar. Filafat Pendidikan Islam Telaah Sistem Pendidikan dan Pemikiran Para Tokohnya (Jakarta: Kalam Mulia. 2011).

Saiful Akhyar. Konseling Islami dan Urgensinya dalam Kesehatan Mental. Tesis. Fakultas Pasca Sarjana dan Pendidikan Doktor Institut Agama Islam Negeri Sunan Kalijaga Yogyakarta. 1990.

Thohari Musnamar. Dasar-dasar Konseptual Bimbingan Konseling Islami (Yogyakarta: UII Press. 1992).

Zulkifli Akbar. Dasar-dasar Konseptual Penanggungan Masalah Bimbingan dan Konseling Islami di Bidang Pernikahan, Kemasyarakatan dan Keagamaan (Yogyakarta: UII. 1987). 